\title{
Biocompatibility and Toxicity of Polylactic Acid/Ferrosoferric Oxide Nanomagnetic Microsphere
}

\author{
Hongzhao Xiang, ${ }^{1}$ Yuanhua Mu, ${ }^{1}$ Chengbo Hu, ${ }^{2}$ and Xiaobing Luo ${ }^{3}$ \\ ${ }^{1}$ College of Materials Science and Engineering, Chongqing Jiaotong University, Chongqing 400074, China \\ ${ }^{2}$ Chongqing Key Laboratory of Environmental Materials \& Remediation Technologies, Chongqing University of Arts and Sciences, \\ Chongqing 402160, China \\ ${ }^{3}$ College of Science, Chongqing University of Posts and Telecommunications, Chongqing 400065, China
}

Correspondence should be addressed to Hongzhao Xiang; xhzscu@163.com

Received 23 November 2016; Accepted 22 January 2017; Published 19 February 2017

Academic Editor: Vidyadhar Singh

Copyright (C) 2017 Hongzhao Xiang et al. This is an open access article distributed under the Creative Commons Attribution License, which permits unrestricted use, distribution, and reproduction in any medium, provided the original work is properly cited.

\begin{abstract}
Magnetic targeted drugs delivery system (MTDDS) is a new targeted drug system, which can greatly reduce the dosage and improve the therapeutic efficiency of medicine. Currently superparamagnetic ferric oxide plays important function as targeted drug in the treatment of tumors, but cytotoxicity was still regarded as side effect in the process of drug. In this paper, we take advantage of drug carrier (ferric oxide) toxicity controlling cancer cell growth in cancer treatment, increasing targeted drug efficiency. We applied the modified chemical precipitation method to prepare polylactic acid (PLA) coated high-purity superparamagnetic $\mathrm{Fe}_{3} \mathrm{O}_{4}$ nanoparticles for targeted drug, characterized PLA/ $\mathrm{Fe}_{3} \mathrm{O}_{4}$ microspheres physical and chemical properties, and then investigated cytotoxicity influence of $\mathrm{PLA} / \mathrm{Fe}_{3} \mathrm{O}_{4}$ nanomagnetic microspheres as carrier for normal liver cells (7701) and liver cancer cells (HePG2) in different concentration; results of MTT and hemolysis and micronucleus test showed that carrier restrained the growth of HePG2 in special concentration, meanwhile the proliferation rate of liver cells was not affected. The study demonstrates that compared with liver cell, liver cancer cells (HepG2) are easy to be disturbed by $\mathrm{PLA} / \mathrm{Fe}_{3} \mathrm{O}_{4}$ nanomagnetic microsphere, which have higher sensitivity and absorption ability. We hope to take advantage of the susceptible property of cancer cells for carriers to improve targeted drug function.
\end{abstract}

\section{Introduction}

Currently magnetic nanoparticles play important function as targeted drug in the treatment of tumors, which easily control the site of drug delivering. The drug can aggregate in lesion site for inhibiting and eliminating tumor growth, besides reducing the dosage of no lesion and thus lowering the side effect of drug on normal tissue [1-3]. Among them, superparamagnetic ferric oxide $\left(\mathrm{Fe}_{3} \mathrm{O}_{4}, \gamma-\mathrm{Fe}_{2} \mathrm{O}_{3}\right.$, and $\left.\mathrm{CO}-\mathrm{Fe}_{2} \mathrm{O}_{4}\right)$ received special attention, in part due to their magnetic properties, crystal structure, chemical stability, and decreased toxicity (LD50 $2000 \mathrm{mg} / \mathrm{kg}$, far higher than the dosage of clinical application). In order to further enhance targeted drug capacity of nanomagnetic particles $[4,5]$, scientists carry out study from three aspects: (1) selecting appropriate polymer as membrane coating particles, which help to increase dispersion and biocompatibility of microsphere; (2) modifying the surface, as nanoparticles may bond with kinds of functional group $\left(-\mathrm{OH},-\mathrm{COOH},-\mathrm{NH}_{2},-\mathrm{CHO}\right.$, etc.) on the surface of material, which are beneficial for connecting important bioactive substance (such as enzyme, cell, and drug) by adsorption or covalent bonding way; (3) improving particles superparamagnetic properties by adjusting diameter of microsphere, thickness of polymer membrane, and so on, which easily lead to targeted drug separation and tropism under magnetic field.

Preparation way of $\mathrm{Fe}_{3} \mathrm{O}_{4}$ nanomagnetic particles usually includes chemical precipitation, oxidation, and pyrolysis method, in which chemical precipitation method is the frequently used method for preparing $\mathrm{Fe}_{3} \mathrm{O}_{4}$ nanomagnetic particles. Polyester (polycaprolactone, polylactide) is widely used functional biomaterial with good biocompatibility and 
biodegradability, which often acts as membrane coating on the surface of magnetic particles. Magnetic microspheres coated by polyester have the very good application prospect in biological medicine. Utkan et al. [6] adsorbed glycolic acid on the surface of $n-\mathrm{Fe}_{3} \mathrm{O}_{4}$ by electrostatic effect and catalyzed CL graft reacting with the terminal hydroxyl through $\mathrm{Sn}(\mathrm{oct})_{2}$, and magnetic component content was about $10-40 \%$ in the magnetic polymer microspheres. In the DMSO solution, PCL has the upper critical solution temperature (UCST) at $35^{\circ} \mathrm{C}$, and the PCL lattice should be destroyed if above the temperature, meanwhile changing solubility, permeability, and other properties. $35^{\circ} \mathrm{C}$ is close to the temperature of the human body and therefore has a potential application in controlled drug release. In addition, $\mathrm{Ni}$ and Ramanujan [7] used similar way that initiated lactide (LA) reaction. In these experiments, researchers usually pay more attention to toxicity effect of drug delivering, releasing process on the cell or tissue in lesion, and biocompatibility of drug carriers. Today there are more researches on polyethylene glycol (PEG), polylactic acid (PLA), and/or poly- $\varepsilon$ caprolactone (PCL) for coating nanoparticles in the internal and external environment [8-16]. The toxicity reduction in human fibroblast cell was reported with superparamagnetic particles coated with pullulan in human skin fibroblast [17]. But few people take notice that carrier materials have certain potential of toxicity effect for cancer cell growth in targeted drug. In this study, at first we prepared $\mathrm{Fe}_{3} \mathrm{O}_{4}$ magnetic nanoparticle coated by PLA and then characterized structure, morphology, and biocompatibility of $\mathrm{PLA} / \mathrm{Fe}_{3} \mathrm{O}_{4}$ microsphere; lastly it was investigated whether or not PLA/ $/ \mathrm{Fe}_{3} \mathrm{O}_{4}$ nanomagnetic microspheres as carrier cause cytotoxicity for growth of normal liver cells and liver cancer cells. This paper focused on toxicity effect of drug carrier to cancer cell proliferation for increasing targeted drug efficiency.

\section{Materials and Methods}

2.1. Materials. Ferrous chloride tetrahydrate $\left(\mathrm{FeCl}_{2} \cdot 4 \mathrm{H}_{2} \mathrm{O}\right)$, ferric chloride hexahydrate $\left(\mathrm{FeCl}_{3} \cdot 6 \mathrm{H}_{2} \mathrm{O}\right)$, and hexamine were the products of the Chengdu Changzheng Chemical Reagent Company; oleic acid was obtained from Sichuan Guoguang Chemical Plant; PLA was purchased from Chengdu Lianhe Chemical Reagent Company.

\subsection{Synthesis of $\mathrm{PLA} / \mathrm{Fe}_{3} \mathrm{O}_{4}$ Microsphere}

$$
\mathrm{Fe}^{2+}+2 \mathrm{Fe}^{3+}+8 \mathrm{OH}^{-}=\mathrm{Fe}_{3} \mathrm{O}_{4}+4 \mathrm{H}_{2} \mathrm{O}
$$

n- $\mathrm{Fe}_{3} \mathrm{O}_{4}$ was synthesized with the chemical precipitation method (see (1)). A certain amount of $\mathrm{FeCl}_{3} \cdot 6 \mathrm{H}_{2} \mathrm{O} 1.7 \mathrm{~g}$ and $\mathrm{FeCl}_{2} \cdot 4 \mathrm{H}_{2} \mathrm{O} 0.6 \mathrm{~g}\left(\mathrm{Fe}^{3+}: \mathrm{Fe}^{2+}=2: 1\right)$ was dissolved in deionized water and added hexamine. Subsequently the solution was poured into a three-mouth flask, with nitrogen protection, and heated to $80^{\circ} \mathrm{C}$, and then ammonia solution was dropped to adjust $\mathrm{pH}$ to $10-11$, keeping temperature at $80^{\circ} \mathrm{C}$ for $1 \mathrm{~h}$ under vigorous stirring, and gained black n$\mathrm{Fe}_{3} \mathrm{O}_{4}$ crystals. Then oleic acid was added, under $80^{\circ} \mathrm{C}$ for $0.5 \mathrm{~h}$, and cooled to room temperature. Excess ammonia was neutralized with hydrochloric acid to $\mathrm{pH} 7, \mathrm{n}-\mathrm{Fe}_{3} \mathrm{O}_{4}$ isolated by centrifugation and magnet processes, and $\mathrm{n}-\mathrm{Fe}_{3} \mathrm{O}_{4}$ washed with ethanol three times to remove excess oleic acid and hexamine. Finally the crystals were collected and dried in a vacuum oven at $60^{\circ} \mathrm{C}$.

$\mathrm{PLA} / \mathrm{Fe}_{3} \mathrm{O}_{4}$ microspheres are prepared as follows: at first $0.5 \mathrm{~g}$ PLA was dissolved in $10 \mathrm{~mL}$ dichloromethane, then solution was put into three-neck bottle, $0.2 \mathrm{~g} \mathrm{Fe}_{3} \mathrm{O}_{4}$ was added, and solution was stirred and heated at $55^{\circ} \mathrm{C}$ for one hour and then centrifuged for 5 minutes. The upper layer of the supernatant liquid was decanted and the precipitates were carefully transferred into a beaker. Finally, it was washed several times with distilled water and ultrasonicated and obtained the suspension of n-PLA/ $\mathrm{Fe}_{3} \mathrm{O}_{4}$ microspheres.

2.3. Instruments. X-ray diffraction (XRD) patterns of the samples were characterized in a Philips X'Pert Pro X-ray diffractometer (Philips, Netherlands). All the samples were irradiated with monochromatized $\mathrm{CuK} \alpha$ radiation $(\lambda=$ $0.154178 \mathrm{~nm})$. A continuous scan rate of $5^{\circ} \mathrm{min}^{-1}$ from $5^{\circ}$ to $80^{\circ}$ of $2 \theta$ was used for samples. Tube voltage and current were $40 \mathrm{kV}$ and $40 \mathrm{~mA}$, respectively. The functional groups were identified by Fourier transformed infrared (FTIR) spectra recorded using a Nicolet 6700 in transmission mode in the range $4000-400 \mathrm{~cm}^{-1}$ using the $\mathrm{KBr}$ pellet method. Transmission electron microscope (TEM) was obtained with a JEOL-2010 (Japan) microscope using an accelerating voltage of $200 \mathrm{kV}$. PLA/ $/ \mathrm{Fe}_{3} \mathrm{O}_{4}$ microspheres were observed by scanning electron microscopy (SEM) (S-450; Hitachi Ltd, Tokyo, Japan).

2.4. Cell and Animal Testing. Cells: human liver cells 7701 and human liver cancer cell HepG2 were provided by Sichuan Provincial People's Hospital, the research center of freezing and thawing. There were 60 Kunming mice: 4 weeks old, SPF grade, half male and half female, weight $(21 \pm 2) \mathrm{g}$, and provided by medical experimental animal center of Huaxi Medical Central Sichuan University (license number: SYXK 2012-0043). There were 14 New Zealand rabbits, male and female, provided by Sichuan University Animal Center (certificate number: 33-016). MTT [3-(4,5-dimethyl-2-thiazolyl)2,5-diphenyl-2H-tetrazolium bromide] was purchased from Sigma (St Louis, MO). The cell experiment was completed in the Nanotechnology Central of Sichuan University.

In order to study $\mathrm{PLA} / \mathrm{Fe}_{3} \mathrm{O}_{4}$ nanomagnetic microsphere biocompatibility and cytotoxicity, we applied MTT assays in vitro to investigate proliferation of samples. First, the 7701 cell and HepG2 cell concentration were adjusted to $1 \times 10^{5} / \mathrm{mL}$ and inoculated on a 96-well culture plate at $100 \mu \mathrm{L} /$ well. The samples were cultured in the culture box at $37^{\circ} \mathrm{C}$ under saturated humidity and $5 \% \mathrm{CO}_{2}$ condition. The supernatant was discarded after 24 hours, and then the culture solution was added; besides primary concentration of $\mathrm{PLA} / \mathrm{Fe}_{3} \mathrm{O}_{4}$ nanomagnetic particle solution was diluted up to $2,5,10$, 15, 20 times. 7701 cell and HepG2 cell were cultured in the magnetic field. The DMEM group was used as the negative control, and a $0.7 \%$ polyacrylamide monomer solution was used as the positive control. Each sample group comprising 
TABLE 1: Results of MTT test of PLA/ $\mathrm{Fe}_{3} \mathrm{O}_{4}$ magnetic microspheres for 7701 cell.

\begin{tabular}{lcccc}
\hline Group & $\mathrm{A} 490(X \pm S)$ & Inhibition rate (\%) & Relative growth rate (\%) & Toxicity grading \\
\hline Negative control (DMEM) & $3.380 \pm 0.106$ & & 100 & 99 \\
$5 \% \mathrm{PLA} / \mathrm{Fe}_{3} \mathrm{O}_{4}$ nanomagnetic fluid & $3.321 \pm 0.085$ & 1 & 102 & 0 \\
$25 \% \mathrm{PLA} / \mathrm{Fe}_{3} \mathrm{O}_{4}$ nanomagnetic fluid & $3.436 \pm 0.054$ & -2 & 98 & 0 \\
$50 \% \mathrm{PLA} / \mathrm{Fe}_{3} \mathrm{O}_{4}$ nanomagnetic fluid & $3.164 \pm 0.167$ & 2 & 103 & 1 \\
$75 \% \mathrm{PLA} / \mathrm{Fe}_{3} \mathrm{O}_{4}$ nanomagnetic fluid & $3.373 \pm 0.084$ & -3 & 96 & 0 \\
$100 \% \mathrm{PLA} / \mathrm{Fe}_{3} \mathrm{O}_{4}$ nanomagnetic fluid & $3.035 \pm 0.267$ & 76 & 24 & 4 \\
Positive control (polyacrylamide) & $0.065 \pm 0.032$ & 4 & 4 \\
\hline
\end{tabular}

$P<0.05$ versus positive control group.

TABLE 2: Results of MTT test of PLA/ $\mathrm{Fe}_{3} \mathrm{O}_{4}$ nanomagnetic microspheres for HePG2 cell sequence.

\begin{tabular}{lcccc}
\hline Group & $\mathrm{A} 490 \mathrm{~nm}(X \pm S)$ & Inhibition rate (\%) & Relative growth rate (\%) & Toxicity grading \\
\hline Negative control (DMEM) & $2.405 \pm 0.263$ & & 100 & 81 \\
$5 \% \mathrm{PLA} / \mathrm{Fe}_{3} \mathrm{O}_{4}$ nanomagnetic fluid & $1.482 \pm 0.307$ & 19 & 85 & 1 \\
$25 \% \mathrm{PLA} / \mathrm{Fe}_{3} \mathrm{O}_{4}$ nanomagnetic fluid & $1.454 \pm 0.225$ & 36 & 64 & 1 \\
$50 \% \mathrm{PLA} / \mathrm{Fe}_{3} \mathrm{O}_{4}$ nanomagnetic fluid & $1.242 \pm 0.093$ & 23 & 77 & 2 \\
$75 \% \mathrm{PLA} / \mathrm{Fe}_{3} \mathrm{O}_{4}$ nanomagnetic fluid & $1.233 \pm 0.158$ & 40 & 60 & 2 \\
$100 \% \mathrm{PLA} / \mathrm{Fe}_{3} \mathrm{O}_{4}$ nanomagnetic fluid & $1.172 \pm 0.103$ & 80 & 20 & 4 \\
Positive control (polyacrylamide) & $0.054 \pm 0.034$ & & 15 & \\
\hline
\end{tabular}

$P<0.01, P<0.01$ versus negative control group.

nine wells was cultured for 72 hours, and $20 \mu \mathrm{L}$ of MTT was then added to each well and vibrated for 10 minutes. The absorbance value was measured at $493 \mathrm{~nm}$ using an immunoenzyme labeler.

The relative cell activity rate was calculated as follows: relative growth rate $\%=\mathrm{OD}$ (optical density) absorbance data of sample/OD absorbance data of negative control $\times 100 \%$. The relative growth rate value was converted into six levels, as indicated in Tables 1 and 2. Levels $0-1$ are acceptable, whereas level 2 should be assessed comprehensively considering cell morphology, and levels 3-5 are unacceptable.

Hemolysis test: a $10 \mathrm{~mL}$ blood sample was taken from a New Zealand rabbit (male, $2.1 \mathrm{~kg}$ ), and $0.5 \mathrm{~mL}$ of $20 \mathrm{~g} / \mathrm{L}$ potassium oxalate was added to sample. Fresh rabbit blood was diluted (dilution ratio $8 \mathrm{~mL}$ blood to $10 \mathrm{~mL}$ normal saline). $\mathrm{n}-\mathrm{Fe}_{3} \mathrm{O}_{4}$ microspheres were washed twice with distilled water, dried, and suspended using normal saline (final concentration $0.1 \mathrm{~g} / \mathrm{mL}$ ). Normal saline was used as the negative control and distilled water as the positive control. Each group consisted of three test tubes. There was a suspension of the materials to be tested, and $10 \mathrm{~mL}$ normal saline and $10 \mathrm{~mL}$ distilled water were added to each tube, which was then placed in a $37^{\circ} \mathrm{C}$ water bath for 30 minutes. Diluted fresh rabbit blood $(0.2 \mathrm{~mL})$ was added to each tube, which was replaced to the $37^{\circ} \mathrm{C}$ water bath for 60 minutes. Then each tube was centrifuged in a dry centrifuge trunnion for 5 minutes at $2500 \mathrm{rpm}$; the supernatant was then removed and OD values were measured with a spectrophotometer. Absorbance values of each group were measured at $545 \mathrm{~nm}$ in hemolytic test. The hemolysis rate $(\%)=(\mathrm{OD}$ absorbance data of sample - OD absorbance data of negative control)/(OD absorbance data of positive control - OD absorbance data of negative control) $\times 100 \%$. If the hemolytic rate is less than $5 \%$, the material will have no hemolytic effect and conform to the requirements of the hemolytic test for biomaterials.

Micronucleus assay: 60 Kunming mice were divided into six groups; each group includes ten mice, aged 4 weeks and weighing 20-22 g, (half male and half female). Injecting $\mathrm{PLA} / \mathrm{Fe}_{3} \mathrm{O}_{4}$ suspension into mice abdomen, the dosage groups were $5,2.5,1.25$, and $0.625 \mathrm{mg} / \mathrm{kg}$. The positive control group used cyclophosphamide $(40 \mathrm{mg} / \mathrm{kg})$ for abdominal injection and the negative control group used normal saline for abdominal injection. The 30-hour injection method was applied: a 24-hour interval between two injections, then a 6hour waits after the second injection, after which time the mice were killed by cervical vertebra dislocation. Narrow smear of the femur was treated by methanol for $5 \mathrm{~min}$ and then observed after Giemsa straining. The micronucleus test includes counting micronucleus number in each of the 1000 polychromatic erythrocytes of mouse, calculating the microcontaining rate of cells. The result was expressed (\%) and significant difference checked among the groups based on Poisson distribution method.

\section{Results and Discussion}

\subsection{Characterization of $\mathrm{PLA} / \mathrm{Fe}_{3} \mathrm{O}_{4}$ Nanoparticle}

3.1.1. XRD Analysis. In Figure 1, the crystal structure of pure $\mathrm{Fe}_{3} \mathrm{O}_{4}$ and PLA coated $\mathrm{Fe}_{3} \mathrm{O}_{4}$ microspheres was analyzed by XRD. In this figure, $\mathrm{Fe}_{3} \mathrm{O}_{4}$ crystal corresponds with face centered cubic (space group: Fd-3m), and lattice parameters of $\mathrm{Fe}_{3} \mathrm{O}_{4}$ are similar to the data of the International Centre for Diffraction Data [JCPDS: 65-3107]. The peak broadening of the XRD pattern can deduce diameter of particles, and according to the Scherrer formula, we can calculate average 


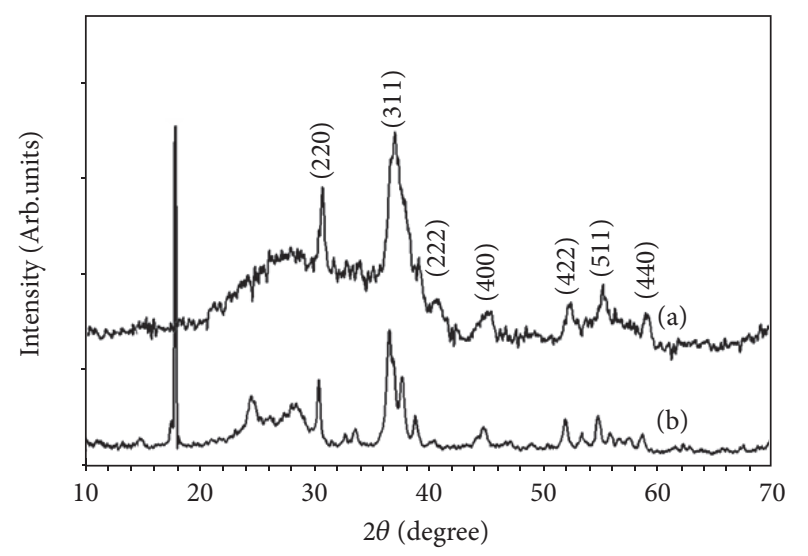

FIGURE 1: XRD pattern for the nanostructure $\mathrm{Fe}_{3} \mathrm{O}_{4}$ (a) and $\mathrm{PLA} / \mathrm{Fe}_{3} \mathrm{O}_{4}$ (b).

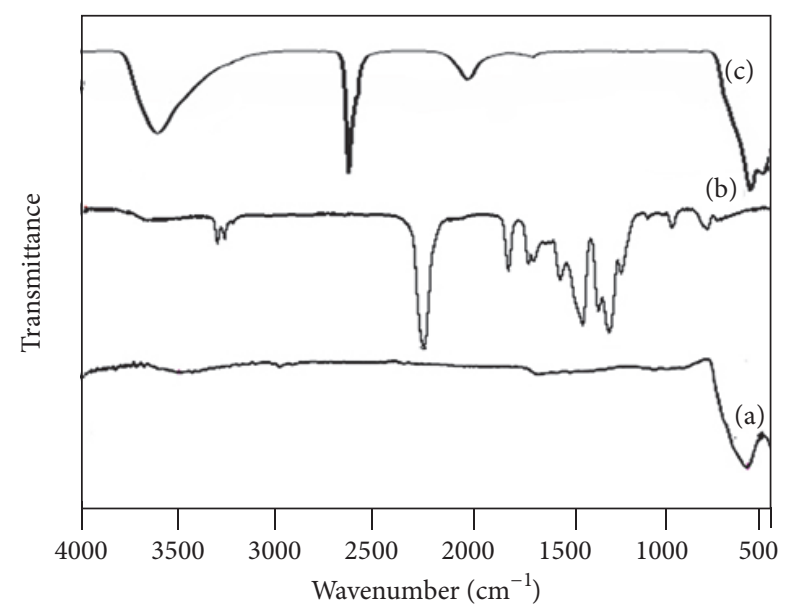

FIgURE 2: FTIR spectra for the $\mathrm{Fe}_{3} \mathrm{O}_{4}$ (a), PLA (b), and PLA/ $\mathrm{Fe}_{3} \mathrm{O}_{4}$ (c).

crystal size, about $40 \mathrm{~nm}$. The intensity of the diffraction peak of (311) plane is stronger than the other peaks. The polymer coated magnetic nanoparticle shows similar XRD peaks, without any peak shift when compared to pure $\mathrm{Fe}_{3} \mathrm{O}_{4}$ nanoparticle. The characteristic peaks of PLA are about $17.8^{\circ}$, and polymer membrane coated particles' surface, whose factors disturb high degree of crystalline and sharpness of peaks.

3.1.2. FTIR Analysis. Figure 2 corresponds to the FTIR spec trum of pure $\mathrm{Fe}_{3} \mathrm{O}_{4}$, PLA, and PLA coated $\mathrm{Fe}_{3} \mathrm{O}_{4}$ nanomagnetic microspheres, which were measured in the range of $400-4000 \mathrm{~cm}^{-1}$. See Figure 2, and pure $\mathrm{Fe}_{3} \mathrm{O}_{4}$ crystal shows the broad and strong absorption peak at $574 \mathrm{~cm}^{-1}$, which corresponds with $\mathrm{Fe}-\mathrm{O}$ bond of $\mathrm{Fe}_{3} \mathrm{O}_{4}$ crystal [18-20]. A broad peak at $3405 \mathrm{~cm}^{-1}$ represents the $\mathrm{O}-\mathrm{H}$ stretching vibration with the presence of water molecules. No other extra peaks were observed and this confirms the high purity of uncoated magnetic nanoparticle.

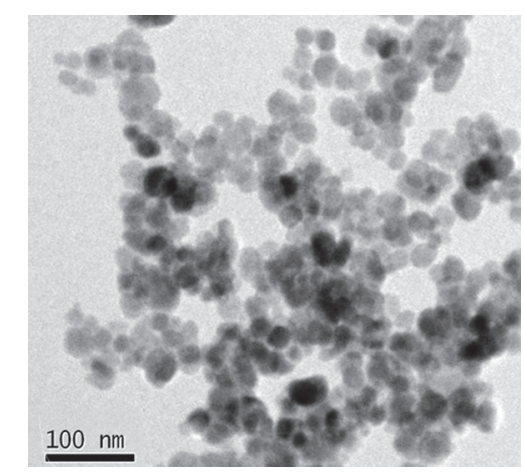

FIGURE 3: TEM images of $\mathrm{n}-\mathrm{Fe}_{3} \mathrm{O}_{4}$ particles.

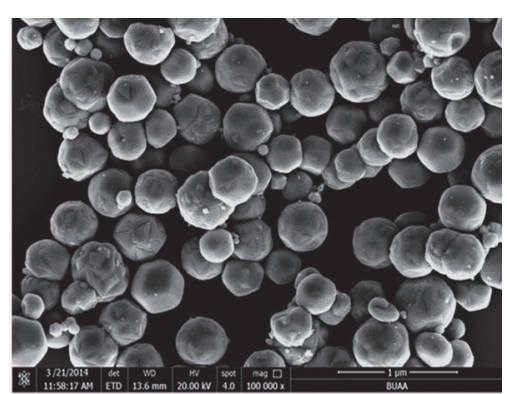

Figure 4: SEM image of PLA/ $\mathrm{Fe}_{3} \mathrm{O}_{4}$ magnetic microspheres.

PLA coated $\mathrm{Fe}_{3} \mathrm{O}_{4}$ magnetic microsphere: the peak at $1180 \mathrm{~cm}^{-1}$ represents the vibration of the $\mathrm{C}-\mathrm{O}$ group, and another peak at $1759 \mathrm{~cm}^{-1}$ corresponds to the $\mathrm{C}=\mathrm{O}$ stretching vibration, maybe due to the LA molecule coating the surface of the $\mathrm{Fe}_{3} \mathrm{O}_{4}$ nanoparticles, so it further confirms the modification of the surface on magnetite nanoparticles by hydrophilic molecules, which facilitate the anisotropic crystal growth. The broad peak at $3400-3450 \mathrm{~cm}^{-1}$ belongs to the $\mathrm{O}-\mathrm{H}$ stretching vibration of hydroxyl groups. The slight shifts in the $\mathrm{Fe}-\mathrm{O}$ bond are in the range $480-590 \mathrm{~cm}^{-1}$ for amine and polymer coated magnetic nanoparticles, and it may be due to the hexamine or the polymers coating the nanoparticles, which can enhance stabilization through some physical interaction on the surface of $\mathrm{Fe}_{3} \mathrm{O}_{4}$ [21]. These results confirm the successful wrapping hexamine and the polymers on the surface of the $\mathrm{Fe}_{3} \mathrm{O}_{4}$ nanoparticles.

3.1.3. TEM/SEM Observation. Figures 3 and 4 are the TEM images of pure $\mathrm{Fe}_{3} \mathrm{O}_{4}$ particles and SEM of $\mathrm{PLA} / \mathrm{Fe}_{3} \mathrm{O}_{4}$ nanomagnetic particles. Photos reveal that diameter of $\mathrm{Fe}_{3} \mathrm{O}_{4}$ nanomagnetic particles is about $40-50 \mathrm{~nm}$, and statistics were gathered from more than one hundred particles, which are consistent with calculation result of the Scherrer formula based on the characteristic peak of XRD, mentioned above.

The SEM image of PLA coated $\mathrm{Fe}_{3} \mathrm{O}_{4}$ magnetic nanoparticles: Figure 4 shows that the monodispersed spherical nanoparticles are around $400-500 \mathrm{~nm}$ in size. Microsphere size controlling is key elements of targeted drug. Reducing particle size can improve the dispersed stability of the microspheres but affects magnetic strength and targeting ability 
to transport. Furthermore, increasing size of microspheres can help to form embolism near the tumor vascular and reduce nutrient supplying tumors. In this experiment, size of $\mathrm{Fe}_{3} \mathrm{O}_{4}$ magnetic microspheres ranges from 400 to $500 \mathrm{~nm}$, and each microsphere consists of many small $\mathrm{Fe}_{3} \mathrm{O}_{4}$ crystals. The aim of loading drug and gene, polylactic acid (PLA) coating $\mathrm{Fe}_{3} \mathrm{O}_{4}$ with oleic acid (PEI), can be realized to modify and enhance the loading ability of magnetic microsphere for drug to improve the transportation efficiency [22].

Some researchers applied coprecipitation method to prepare microsphere. Preparation of $\mathrm{Fe}_{3} \mathrm{O}_{4}$, precipitation of polymer, and coating nanoparticles are in the same environment. Polymer can be used to reduce aggregation and improve dispersibility of particles by changing the intrinsic properties of magnetic nanoparticles such as size, surface charge, and reactivity. The growth of nanocrystal can be controlled by the interface with organic components or polymer in one-step synthesis. In some experiments, researchers need to modify surface of nanoparticles with several organic and inorganic components before connecting with polymer; they usually divide synthesis into several steps, which are favorable to control reaction condition.

We investigated cytotoxicity influence of $\mathrm{PLA} / \mathrm{Fe}_{3} \mathrm{O}_{4}$ nanomagnetic microspheres as carrier, hoping to decrease influence of other organic and inorganic components as possible. In one-step method, $\mathrm{Fe}_{2} \mathrm{O}_{3}$ particles, surfactant, and organic components can be introduced in microsphere together, making it difficult for separation and disturbing result of cytotoxicity test. On the contrary, two-step method can easily control precipitating of $n-\mathrm{Fe}_{3} \mathrm{O}_{4}$, crystal growth, modification, washing, and drying process.

Besides hexamine was added in the process of preparing $\mathrm{Fe}_{3} \mathrm{O}_{4}$ nanoparticles. Adding surfactant is to reduce the surface energy and enhance the formation of monodispersed spherically shaped nanoparticles, which can control the growth of spherical $\mathrm{Fe}_{3} \mathrm{O}_{4}$. Hexamine contains one or more functional group such as amide, hydroxyl, and carboxyl groups, which can act as the reaction site to enhance the reaction rate and fine orientation on the surface of $\mathrm{Fe}_{3} \mathrm{O}_{4}$. The kinetics of crystal growth leads to the uniform distribution of agglomeration free nanoparticles. When the particles exceed their critical size, the hexamine molecules act not only as shape controlling agents but also as stabilizing agents to control the growth of the magnetic nanoparticles.

\subsection{Toxicity and Biocompatibility Study In Vitro and In Vivo}

3.2.1. MTT Test. Biocompatibility and toxicity of $\mathrm{PLA} / \mathrm{Fe}_{3} \mathrm{O}_{4}$ nanomagnetic microspheres were evaluated by MTT (cytotoxicity test), hemolysis test, and micronucleus test.

Tables 1 and 2 show result of MTT of $\mathrm{PLA} / \mathrm{Fe}_{3} \mathrm{O}_{4}$ microspheres for 7701 cell and HePG2 cell. Table 1 indicates that cytotoxicity of $\mathrm{PLA} / \mathrm{Fe}_{3} \mathrm{O}_{4}$ microsphere has no effect on growth of normal liver cell at low concentration; Table 2 shows that toxicity grade of $\mathrm{PLA} / \mathrm{Fe}_{3} \mathrm{O}_{4}$ microsphere ranges from 1 to 2, as mentioned above, and at the level of 2, survival and proliferation of cell not only consider toxicity grade, but also assess cell's morphology comprehensively, which means

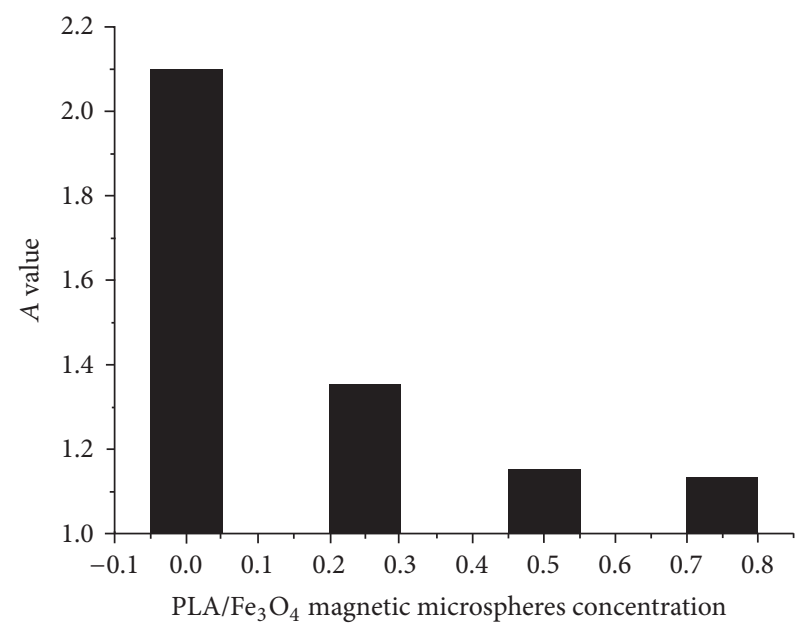

FIgURE 5: Relationship between PLA/ $\mathrm{Fe}_{3} \mathrm{O}_{4}$ magnetic microspheres concentration and hepatocyte HePG2 activity.

TABLE 3: Results of hemolysis test of PLA/ $/ \mathrm{Fe}_{3} \mathrm{O}_{4}$ magnetic nanoparticles extract liquid.

\begin{tabular}{lcccc}
\hline Group & \multicolumn{3}{c}{ A value } & Mean A value \\
\hline $\begin{array}{l}\text { Negative control } \\
\text { (physiological saline) }\end{array}$ & 0.018 & 0.017 & 0.016 & 0.0173 \\
$\begin{array}{l}\text { Experimental } \\
\begin{array}{l}\text { Positive control } \\
\text { (distilled water) }\end{array}\end{array}$ & 0.020 & 0.024 & 0.023 & 0.0221 \\
\hline
\end{tabular}

that growth of HepG2 is easy to be disturbed by PLA/Fe $\mathrm{O}_{4}$ nanomagnetic microsphere at special concentration.

We investigated relationship between the different concentration of $\mathrm{PLA} / \mathrm{Fe}_{3} \mathrm{O}_{4}$ magnetic nanoparticles and inhibition rate for liver cancer cell HepG2 (see Figure 5). $\mathrm{PLA} / \mathrm{Fe}_{3} \mathrm{O}_{4}$ nanomagnetic microspheres used as drug carrier have no obvious toxicity to normal liver cells but inhibited liver cancer cells proliferation, which can help targeted drugs to treat cancer and increases the efficacy of the drugs.

3.2.2. Hemolysis Test. The hemolytic test is considered to be a supplementary test for assessment of cytotoxicity. It is used to evaluate if erythrocytes should dissolve and release hemoglobin after direct contact of the biomaterial with blood. It can be a sensitive measure of the biomaterial influence on erythrocytes and plays an important role in evaluation of biological safety. According to Table 3, introduced data of in vitro hemolysis test into the formula of hemolysis [7], result showed that hemolytic data of $\mathrm{PLA} / \mathrm{Fe}_{3} \mathrm{O}_{4}$ nanomagnetic microsphere was $0.62 \%$, far less than the standard (5\%), and showed no hemolysis response, and the requirements of the hemolytic test were met in biomaterials.

3.2.3. Micronucleus Test. The micronucleus test is a strategy to rapidly assess chromosomal damage and interference with mitosis caused by biomaterials. See Table 4; the test found no significant difference for micronucleus formation of the 
TABLE 4: Results of micronucleus test of PLA/ $\mathrm{Fe}_{3} \mathrm{O}_{4}$ nanomagnetic fluid $(n=10)$.

\begin{tabular}{lccc}
\hline Group & $\begin{array}{c}\text { Numbers of } \\
\text { polychromatocytes }\end{array}$ & $\begin{array}{c}\text { Numbers of } \\
\text { micronucleuses in } \\
\text { polychromatocytes }\end{array}$ & $\begin{array}{c}\text { Micronucleus rates } \\
(\%)\end{array}$ \\
\hline Negative control (physiological saline) & 10000 & 26 & 24 \\
$5.00 \mathrm{~g} / \mathrm{Kg} \mathrm{PLA} / \mathrm{Fe}_{3} \mathrm{O}_{4}$ nanomagnetic fluid & 10000 & 24 & 23 \\
$4.00 \mathrm{~g} / \mathrm{Kg} \mathrm{PLA} / \mathrm{Fe}_{3} \mathrm{O}_{4}$ nanomagnetic fluid & 10000 & 20 & 21 \\
$2.50 \mathrm{~g} / \mathrm{Kg} \mathrm{PLA} / \mathrm{Fe}_{3} \mathrm{O}_{4}$ nanomagnetic fluid & 10000 & 21 & 19 \\
$1.25 \mathrm{~g} / \mathrm{Kg} \mathrm{PLA} / \mathrm{Fe}_{3} \mathrm{O}_{4}$ nanomagnetic fluid & 10000 & 291 & 22 \\
Positive control (cyclophosphamide) & 10000 & 289 \\
\hline
\end{tabular}

mice in bone marrow between the material and the negative control group. However, a significant difference for data of the positive control group was noted. Based on these data, the experimental material does not induce deformations or mutations.

3.3. Discussion. Magnetic targeted drugs delivery system (MTDDS) is a new targeted drug system in recent years, which have the immense potential to treat some diseases, especially malignant tumors and other major diseases. MTDDS method can reduce the dosage and side effects and improve the therapeutic efficiency of medicine. Usually magnetic targeted drug delivery system consists of magnetic polymer microspheres and drug, and drug combines with microspheres by physical adsorption, entrapment, and chemical bonding methods. Most of drug loading microspheres play function through arterial injection, and then microspheres were placed and aggregated in lesion position under effect of the magnetic field, take advantage of embolism effect, and release drug, thereby achieving the purpose of treatment. Thus MTDDS can greatly reduce the dosage and side effects in the treatment of disease and improve the therapeutic efficiency. In 1960, Freeman first reported that the crystal (5$100 \mathrm{~nm}$ ) of iron was introduced into the vascular system and iron accumulated in special part of the body under controlled external magnetic field. Turcu and colleagues [23] prepared magnetic polymethyl methacrylate microspheres containing indomethacin, intravenously injected, and employed magnetic field in the rat tail for $60 \mathrm{~min}$; drug concentration in the rat tail was 60 times higher than that of control group. In recent years, magnetic polymer microspheres as drug carrier for liver cancer therapy attracted scientist's attention $[24,25]$. Lbbe and colleagues first applied magnetic polymer microsphere in clinical trials, they used magnetic microspheres $(100 \mathrm{~nm})$ containing epirubicin treating 14 patients with advanced stage hepatoma, and results showed that the method of cure reduces the side effect of drugs greatly and, at the same time, realized aggregation of microspheres in targeted area under the magnetic field. However the MRI showed that part of microspheres were detained in the lungs.

There are still some problems for $\mathrm{Fe}_{3} \mathrm{O}_{4}$ magnetic microsphere as carrier being used in the targeted drug field, especially cytotoxicity. Many studies have demonstrated toxicity of $\mathrm{Fe}_{3} \mathrm{O}_{4}$ nanoparticles in biological systems. Currently it is not clear whether $\mathrm{Fe}_{3} \mathrm{O}_{4}$ alone or combination of other harmful agents (polymer membrane and functional group) causes the danger. Some scientists deduced the phenomenon to the ferric oxide nanoparticle releasing active oxygen and causing oxidative stress and inflammation by the RES (reticuloendothelial system).

So researchers focus on drug release; lowering or eliminating toxicity of targeted drug often follows three elements: (1) the skeleton material in the body can be metabolism and metabolites ought to have no toxicity and be excreted in a certain period; (2) diameter of nonbiodegradable particles $\left(\mathrm{Fe}_{3} \mathrm{O}_{4}\right)$ contained in microspheres has to be less than $20 \mu \mathrm{m}$ [26]; (3) magnetic polymer microspheres should have strong magnetic response potential and high surface area. But they often ignored the value for toxicity of drug carrier. This study investigated influence of carrier toxicity for proliferation of liver cells 7701 and liver cancer cell HepG2 at different concentrations. MTT results showed that carrier restrained the growth of HePG2 in special concentration. Meanwhile, the proliferation rate of liver cells was right. We attributed this result to two factors: (1) liver cancer cells have high sensitivity. Compared with liver cell, HepG2 is easy to be disturbed by $\mathrm{PLA} / \mathrm{Fe}_{3} \mathrm{O}_{4}$ nanomagnetic fluid toxicity, so the growth of HepG2 is inhibited; (2) absorption ability of cancer cell is stronger than normal cells if cocultured with $\mathrm{PLA} / \mathrm{Fe}_{3} \mathrm{O}_{4}$ nanomagnetic solution. So we can take advantage of drug carrier toxicity controlling cancer cell growth in cancer treatment.

In the paper, $\mathrm{Fe}_{3} \mathrm{O}_{4}$ nanoparticles are modified with oleic acid, its surface bond with oleic acid chains, and hydroxyl group, so it is amphipathy. If $\mathrm{n}-\mathrm{Fe}_{3} \mathrm{O}_{4}$ were placed in the PLA solution environment, amphipathy of $\mathrm{Fe}_{3} \mathrm{O}_{4}$ nanoparticles tends to be self-assembled by bonding with carboxyl group and hydroxyl groups on the surface of $\mathrm{Fe}_{3} \mathrm{O}_{4}$ nanoparticles; surface charge of $\mathrm{PLA} / \mathrm{Fe}_{3} \mathrm{O}_{4}$ microspheres can affect the dispersion, magnetic strength, and size of microspheres in solvents.

\section{Conclusions}

In the study, we successfully prepared $\mathrm{PLA} / \mathrm{Fe}_{3} \mathrm{O}_{4}$ nanomagnetic microsphere. Biocompatibility was evaluated by a series test in vivo and in vitro, MTT experiments showed that the toxicity of the material in normal liver cell was between Grade 0 and Grade $1, \mathrm{Fe}_{3} \mathrm{O}_{4}$ nanomagnetic microsphere inhibited liver cancer cell proliferation, the material lacked hemolysis 
activity, and micronucleus testing showed no genotoxic effects. Test demonstrated that the $\mathrm{Fe}_{3} \mathrm{O}_{4}$ nanoparticle had no effect on the main organs and blood biochemistry in mice, its performance conforms to clinical requirements, and its biocompatibility conforms to the standard for medical material. We investigated toxicity effect of drug carrier for different cells. As liver cancer cells are susceptible to $\mathrm{PLA} / \mathrm{Fe}_{3} \mathrm{O}_{4}$ nanomagnetic fluid toxicity, $\mathrm{PLA} / \mathrm{Fe}_{3} \mathrm{O}_{4}$ carrier has certain potential to restrain liver cancer cells growth. So applying PLA/ $\mathrm{Fe}_{3} \mathrm{O}_{4}$ nanomagnetic microsphere as drug carrier not only has good targeting capacity, but also helps to control cancer cell growth by toxicity effect of carrier and enhance targeted drug efficiency.

\section{Competing Interests}

The authors declare that they have no competing interests.

\section{Acknowledgments}

This work was financially supported by Research Foundation of the Chongqing Jiaotong University (16JDKJC-A035) and Chongqing Post-Doctoral Study Foundation (Xm2016128).

\section{References}

[1] L. H. Reddy, J. L. Arias, J. Nicolas, and P. Couvreur, "Magnetic nanoparticles: design and characterization, toxicity and biocompatibility, pharmaceutical and biomedical applications," Chemical Reviews, vol. 112, no. 11, pp. 5818-5878, 2012.

[2] L. Biao, G. Jian-guo, W. Qi et al., "Preparation of nanometer cobalt particles by polyol reduction process and mechanism research," Materials Transactions, vol. 46, no. 4, pp. 1865-1867, 2010.

[3] Z. Ying, J. Shengming, Q. Guanzhou et al., "Preparation of ultrafine nickel powder by polyol method and its oxidation product," Materials Science and Engineering B, vol. 122, no. 1, pp. 222-225, 2013.

[4] C.-C. Huang, K.-Y. Chuang, C.-P. Chou et al., "Size-control synthesis of structure deficient truncated octahedral $\mathrm{Fe}_{3-\delta} \mathrm{O}_{4}$ nanoparticles: high magnetization magnetites as effective hepatic contrast agents," Journal of Materials Chemistry, vol. 21, no. 20, pp. 7472-7479, 2011.

[5] H. T. Hai, H. Kura, M. Takahashi, and T. Ogawa, "Facile synthesis of $\mathrm{Fe}_{3} \mathrm{O}_{4}$ nanoparticles by reduction phase transformation from $\gamma-\mathrm{Fe}_{2} \mathrm{O}_{3}$ nanoparticles in organic solvent," Journal of Colloid and Interface Science, vol. 341, no. 1, pp. 194-199, 2010.

[6] G. Utkan, F. Sayar, P. Batat, S. Ide, M. Kriechbaum, and E. Pişkin, "Synthesis and characterization of nanomagnetite particles and their polymer coated forms," Journal of Colloid and Interface Science, vol. 35, no. 2, pp. 372-379, 2011.

[7] S. Ni and R. V. Ramanujan, "Doxorubicin loaded PLA coated iron oxide nanoparticles for targeted drug delivery," Materials Science and Engineering C, vol. 30, no. 7, pp. 484-490, 2010.

[8] S. Liu, Y. Han, R. Qiao et al., "Investigations on the interactions between plasma proteins and magnetic iron oxide nanoparticles with different surface modifications," Journal of Physical Chemistry C, vol. 114, no. 49, pp. 21270-21276, 2010.
[9] A. J. Cole, A. E. David, J. Wang, C. J. Galbán, H. L. Hill, and V. C. Yang, "Polyethylene glycol modified, cross-linked starchcoated iron oxide nanoparticles for enhanced magnetic tumor targeting," Biomaterials, vol. 32, no. 8, pp. 2183-2193, 2011.

[10] N. Arsalani, H. Fattahi, and M. Nazarpoor, "Synthesis and characterization of PVP-functionalized superparamagnetic $\mathrm{Fe}_{3} \mathrm{O}_{4}$ nanoparticles as an MRI contrast agent," Express Polymer Letters, vol. 4, no. 6, pp. 329-338, 2010.

[11] D.-H. Zhang, G.-D. Li, J.-X. Li, and J.-S. Chen, "One-pot synthesis of $\mathrm{Ag}-\mathrm{Fe}_{3} \mathrm{O}_{4}$ nanocomposite: a magnetically recyclable and efficient catalyst for epoxidation of styrene," Chemical Communications, no. 29, pp. 3414-3416, 2008.

[12] A. Sugunan, H. C. Warad, M. Boman, and J. Dutta, "Zinc oxide nanowires in chemical bath on seeded substrates: role of hexamine," Journal of Sol-Gel Science and Technology, vol. 39, no. 1, pp. 49-56, 2006.

[13] W. Jiang, Z. Sun, F. Li et al., "A novel approach to preparing magnetic protein microspheres with core-shell structure," Journal of Magnetism and Magnetic Materials, vol. 323, no. 5, pp. 435-439, 2011.

[14] E. Iglesias-Silva, J. Rivas, L. M. León Isidro, and M. A. LópezQuintela, "Synthesis of silver-coated magnetite nanoparticles," Journal of Non-Crystalline Solids, vol. 353, no. 8-10, pp. 829-831, 2007.

[15] Z. Zou, A. G. Xuan, Z. G. Yan, Y. X. Wu, and N. Li, "Preparation of $\mathrm{Fe}_{3} \mathrm{O}_{4}$ particles from copper/iron ore cinder and their microwave absorption properties," Chemical Engineering Science, vol. 65, no. 1, pp. 160-164, 2010.

[16] J. Liang, L. Li, M. Luo, J. Fang, and Y. Hu, "Synthesis and properties of magnetite $\mathrm{Fe}_{3} \mathrm{O}_{4}$ via a simple hydrothermal route," Solid State Sciences, vol. 12, no. 8, pp. 1422-1425, 2010.

[17] Y. Yin, S. Zhou, C. Min, and L. Wu, "Preparation of rattle-type magnetic mesoporous carbon spheres and their highly efficient adsorption and separation, Journal of Colloid and Interface Science, vol. 361, no. 2, pp. 527-533, 2011.

[18] W. Beck, C. G. Souza, T. L. Silva, M. Jafelicci, and L. C. Varanda, "Formation mechanism via a heterocoagulation approach of FePt nanoparticles using the modified polyol process," The Journal of Physical Chemistry C, vol. 115, no. 21, pp. 10475-10482, 2011.

[19] Y. Zhan, R. Zhao, F. Meng et al., "Oriented growth of magnetite along the carbon nanotubes via covalently bonded method in a simple solvothermal system," Materials Science and Engineering $B$, vol. 176, pp. 779-784, 2011.

[20] J. Töpfer and A. Angermann, "Nanocrystalline magnetite and $\mathrm{Mn}-\mathrm{Zn}$ ferrite particles via the polyol process: synthesis and magnetic properties," Materials Chemistry and Physics, vol. 129, no. 1, pp. 337-342, 2011.

[21] B. Wang, B. Wang, P. Wei, X. Wang, and W. Lou, "Controlled synthesis and size-dependent thermal conductivity of $\mathrm{Fe}_{3} \mathrm{O}_{4}$ magnetic nanofluids," Dalton Transactions, vol. 41, no. 3, pp. 896-899, 2012.

[22] Z. Pu, M. Cao, J. Yang, K. Huang, and C. Hu, "Controlled synthesis and growth mechanism of hematite nanorhombohedra, nanorods and nanocubes," Nanotechnology, vol. 17, no. 3, pp. 799-804, 2006.

[23] R. Turcu, O. Pana, A. Nan, I. Craciunescu, O. Chauvet, and C. Payen, "Polypyrrole coated magnetite nanoparticles from water based nanofluids," Journal of Physics D: Applied Physics, vol. 41, no. 24, Article ID 245002, 2008. 
[24] E. Maltas, M. Ozmen, H. C. Vural, S. Yildiz, and M. Ersoz, "Immobilization of albumin on magnetite nanoparticles," Materials Letters, vol. 65, no. 23-24, pp. 3499-3501, 2011.

[25] X. Wang, G. Xi, Y. Liu, and Y. Qian, "Controllable synthesis of PbSe nanostructures and growth mechanisms," Crystal Growth \& Design, vol. 8, no. 4, pp. 1406-1411, 2008.

[26] M. Mahmoudi, A. Simchi, M. Imani, P. Stroeve, and A. Sohrabi, "Templated growth of superparamagnetic iron oxide nanoparticles by temperature programming in the presence of poly(vinyl alcohol)," Thin Solid Films, vol. 518, no. 15, pp. 4281-4289, 2010. 

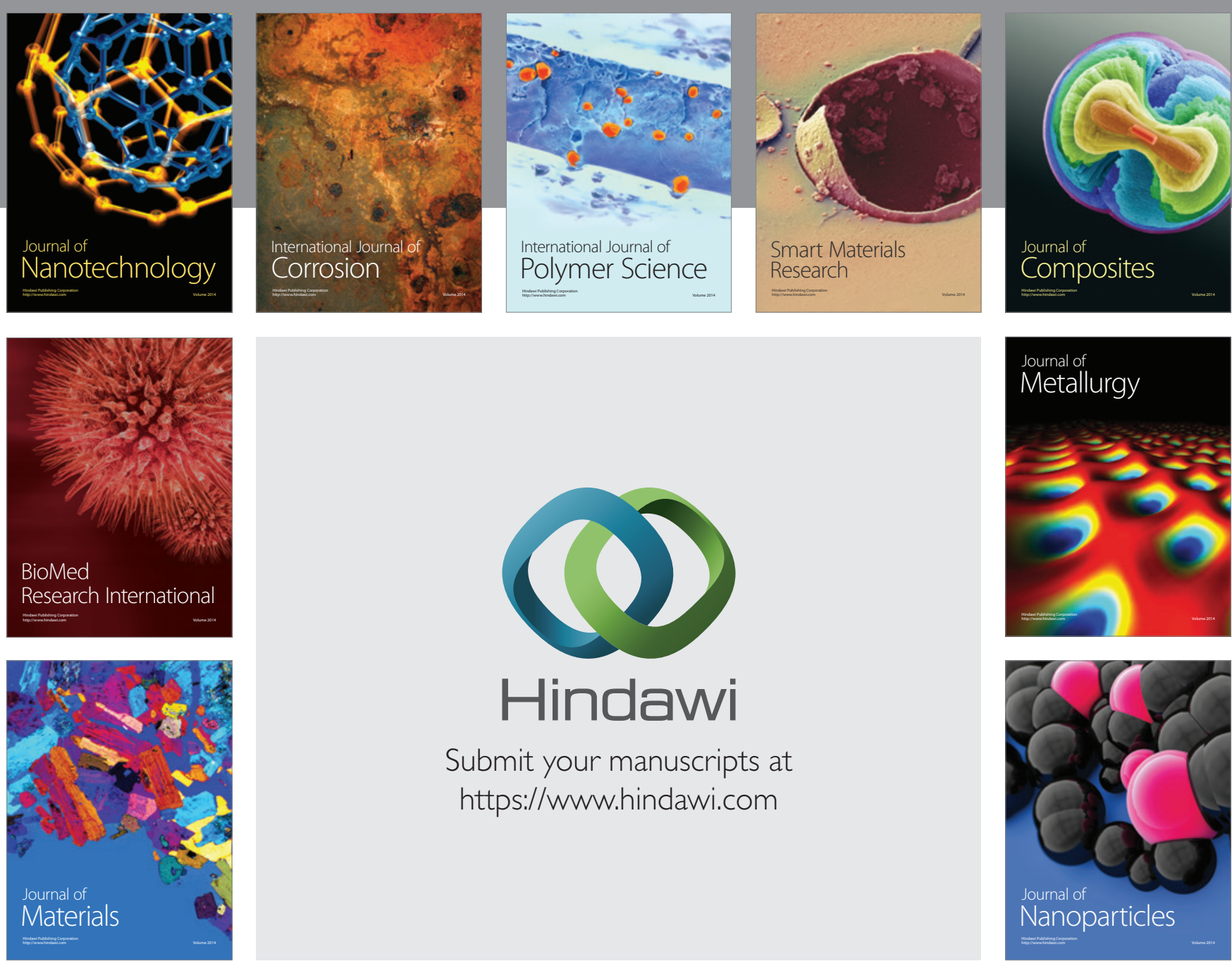

\section{Hindawi}

Submit your manuscripts at

https://www.hindawi.com

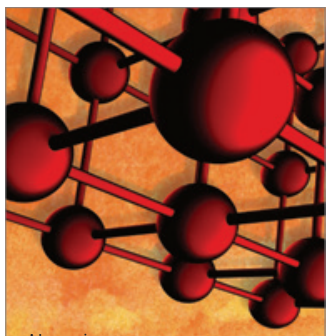

Materials Science and Engineering
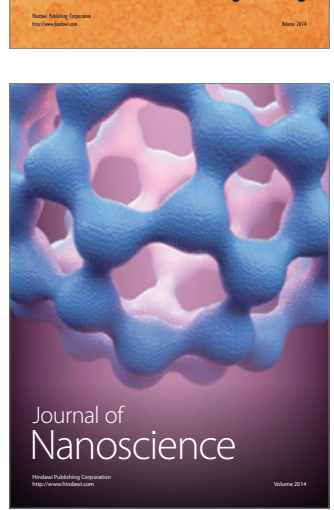
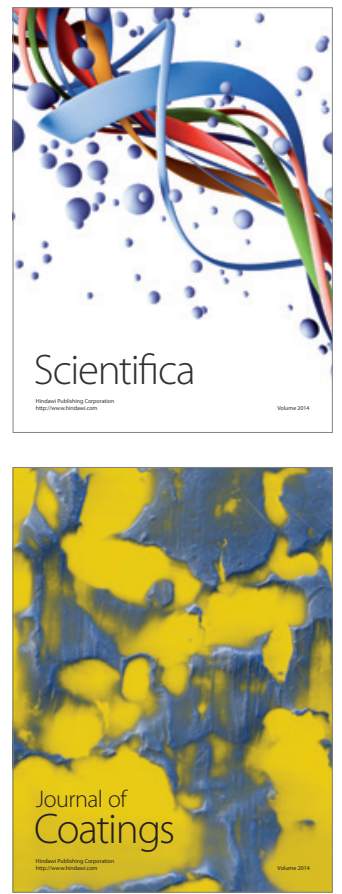
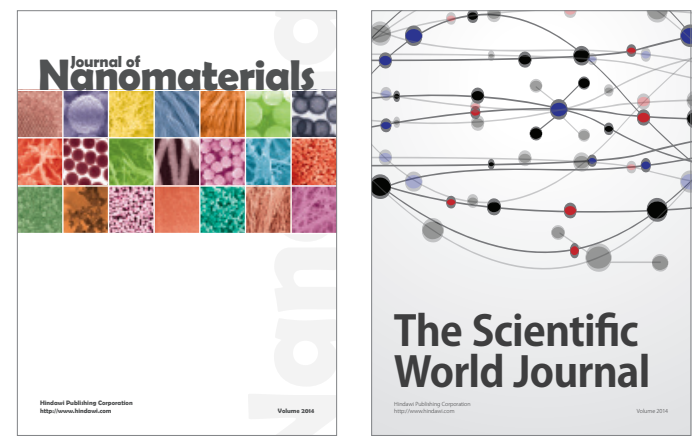

The Scientific World Journal
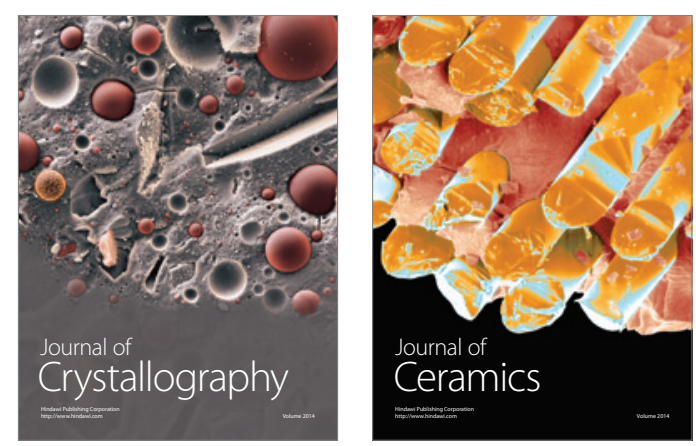
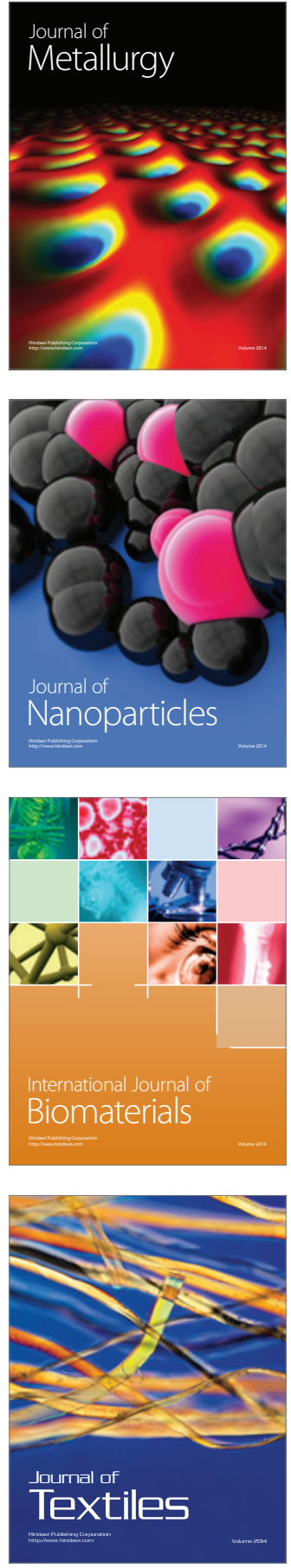